\title{
EFEKTIVITAS MANAJEMEN KEPEMIMPINAN KEPALA MADRASAH DI MAN 1 KABUPATEN GORONTALO
}

\author{
Buhari Luneto \\ Institut Agama Islam Negeri Sultan Amai Gorontalo \\ Email: buhariluneto@iaingorontalo.ac.id
}

\begin{abstract}
ABSTRAK
Artikel ini bertujuan untuk melihat sejauh mana kontribusi kepemimpinan kepala Madrasah dalam meningkatkan kualitas dengan menggerakan seluruh sumber daya yang ada dalam lingkungan lembaga yang dipimpinnya. Metode yang digunakan dalam penelitian ini adalah kualitatif. Hasil penelitian menunjukan bahwa efektivitas manajemen kepala Madrasah dapat dilakukan dengan cara membagi tugas kepada seluruh aparatur sesuai dengan latar belakang kemampuan masing-masing. Dengan kata lain bahwa melalui penerapan manajemen kolegial kolektif dan keterbukaan sehingga berimplikasi secara keseluruhan terhadap keberhasilan program pendidikan di MAN 1 Kabupaten Gorontalo.
\end{abstract}

Kata Kunci: Efektivitas, Manajemen, Kepemimpinan

\begin{abstract}
This article aims to see to what extent the leadership contribution of the Madrasah head in improving quality by mobilizing all available resources within the institution he leads. The method used in this research is qualitative. The results showed that the management authority of the head of the Madrasah could be carried out by dividing tasks among all apparatus according to the background of their respective abilities. In other words, the implementation of collective collegial management and openness has implications for the overall education program in MAN 1 Gorontalo District.
\end{abstract}

Keywords: Effectiveness, Management, Leadership

\section{PENDAHULUAN}

Madrasah sebagai pusat Pendidikan formal, lahir dan berkembang dari pemikiran efesiensi dan efektivitas didalam pemeberian Pendidikan kepada warga masyarakat. Lembaga Pendidikan formal atau mandrasah lahir dan tumbuh dari dan untuk masyarakat bersangkutan. Artinya, madrasah sebagai pusat Pendidikan formal merupakan perangkat masyarakat yang diserahi kewajiban pemberian Pendidikan. Perangkat ini ditata dan dikelola secara formal, mengikuti Haluan yang pasti dan diberlakukanya di masyarakat bersangkutan. Haluan tersebut tercermin dalam bagimana manajemen Pendidikan yang bermutu dalam Lembaga tertata secara baik dan terarah. Sejalan dengan pelaksanaan otonomi daerah, maka sudah waktunya apabila manajemen Pendidikan nasional didesentralisasikan. 
Otonomi daerah sejalan dengan dimensi pembangun dari pengelolaan sikdiknas, pelaksanaan kekhasan Pendidikan nasional akan terwujud seiring besarnya partisipasi masyarakat dalam mengelolah kebutuhanya. Desentralisasi manajemen Pendidikan nasional bukanlah berarti meremehkan doktrin wawasan nusantara dan ketahanan nasional sebaliknya. Desentralisasi manajemen Pendidikan kepada kebutuhan daerah. ${ }^{1}$

Apabila manajemen Pendidikan sejak taman kanak-kanak sampai universitas berada pada tingkat pengelolaan yang nyata yakni pada daerah masing-masing, maka kebutuhan pembangunan didaerah, kebutuhan tenagatenaga terampil untuk pembangunan daerah akan dapat diketahui dan dikelola secara baik. Desentralisasi manajemen Pendidikan nasional berarti pula mengalakkan partisipasi masyarakat dalam penyelenggaraan Pendidikan nasional, mengorganisasi diri dan munculnya kepemimpinan lokal (local genius). Dengan sendirinya masalah output Pendidikan national dalam bentuk link and match bukanlah merupakan suatu masalah karena akan tumbuh dengan sendirinya dari penerapan desentralisasi manajemen Pendidikan.

Dengan semakin tingginya partisipasi masyarakat khususnya dalam penyelenggaraan Pendidikan national maka perencanaan dari bawah yang mengikutisertakan partisipasi rakyat hasilnya akan lebih efesien. Dewasa ini banyak kritik dilimpahkan dengan mengurangi system manajemen kita yang serba kaku dari Pendidikan tinggi yang serba sentralistik, sehingga system tersebut sulit untuk dapat bersaing di dalam era globalisasi. Termasuk metodologi yang dilaksanakan dewasa ini terlalu sentralistik dan akademik serta cenderung kearah indoktrinasi sehingga tidak cocok dengan perkembangan kejiwaan dari peserta didik. Di madrasah, kelompok ini sebenarnya diharapkan mampu terserap diperguruan tinggi agama, akan tetapi kenyataan kebanyakan dari mereka lebih memilih perguruan tinggi umum sekalipun swasta karena tidak mampu bersaing di UMPTN. Fenomena tersebut tentulah banyak factor penyebabnya, selain kemampuan ekonomi orang tua, kualitas madrasah agama (MA) yang secara umum belumlah dapat bersaing secara penuh dengan sekolah umum (SMA). ${ }^{2}$ Salah satu factor penyebabnya adalah kualitas madrasah agama (MA) yang masih dibawah madrasah umum, kualitas sebuah Lembaga Pendidikan (sekolah/madrasah) tidak dapat dilepasakan dari kinerja dari seorang kepala sekolah/madrasah, kinerja seorang kepala sekolah/madrasah sangat ditentukam pula oleh banyak hal. Jika seorang kepala madrasah memiliki visi misi yang kuat

h. 3

${ }^{1}$ Wahjosumidjo, Kepemimpinan Kepala Madrasah, Yogyakarta: Pustaka pelajar, 1999).,

${ }^{2}$ Anwar, Herson. "Implementation of Education Management Standard in the Guidance of Private Islamic High School." Jurnal Pendidikan Islam UIN Sunan Gunung Djati 4.1 (2018): 7586. 
serta kinerja yang baik, maka Lembaga madrasah yang dimaksud akan ikut Tangguh dan mempunyai daya saing yang tinggi dengan madrasah umum.

Sebuah madrasah adalah organisasi yang kompleks dan unik, sehingga memerlukan tingkat koordinasi yang tinggi, oleh sebab itu kepala madrasah yang berhasil ialah tercapainya tujuan madrasah serta tujuan individu yang ada dalam lingkungan madrasah, harus memahami dan menguasai organisasi dan hubungan kerja sama antara individu. ${ }^{3}$ Dalam menjalankan proses Pendidikan tentunya terdapat satu system yang merupakan mata rantai yang tidak dapat terpisahkan satu sama lain. Karena pentingnya system ini tentunya harus ada orang yang akan mengendalikan system ini, sejalan dengan hal itu orang ornag dimaksud debagai pengendali dalam madrasah tersebut adalah kepala sekolah.

Disetiap madrasah jabatan tertinggi dipengang oleh kepala madrasah sebagai pengendali dalam menjalankan proses yang berkaitan dengan Pendidikan, termasuk didalam menciptakan kondisi pembelajara yang baik. Dalam konteks ini kepala madrasah yang memegang kepemimpinan dalam madrasah tersebut. Pada posisi seperti ini tentunya usaha yang dilakukan oleh kepala madrasah sangat terkait dengan adanya pelaksanaan manajemen Pendidikan di madrasah. Karena begitu pentingnya keberadaan kepala madrasah sehingga ia dituntut untuk mampu memahami sekaligus melaksanakan tugas dan fungsinya, posisi kepala madrasah akan sangat mempengaruhi kinerja madrasah tersebut, kepala madrasah memiliki fungsi ganda dalam melakukan manajemen madrasah, kepala madrasah dapat menjadi tokoh sentra maju mundurnya madrasah, karena pentingnya posisi dan jabatan kepala madrasah ini, maka kepala madrasah seharusnya memiliki visi dan misi serta strategi manajemen Pendidikan yang memiliki orientasi pada mutu.

Dengan demikian kepala madrasah mempunyai kewenangan besar dalam upaya meningkatkan kualitas Pendidikan, oleh karena itu mutu seorang kepala madrasah akan selalu menjadi cermin bagi lingkungan madrasah itu sendiri. Mutu Pendidikan merupakan sebuah akumulasi terpadu antara input, proses dan output. Input adalah sumber daya yang tersedia dalam menunjang proses Pendidikan dan pengajaran, proses merupakan kualitas proses pembelajaran itu sendiri. Sedangkan output berkaitan dengan kinerja madrasah. Kinerja madrasah adala prestasi madrasah yang dihasilkan dan proses/ perilaku madrasah.

\section{METODE PENELITIAN}

Penelitian ini menggunakan pendekatan kualitatif dengan teknik pengumpulan data yaitu observasi dan wawancara yang dilakukan di MAN 1 Kabupaten Gorontalo.

${ }^{3}$ Lihat, Wahjosumidjo, Kepemimpinan Kepala Madrasah, Yogyakarta: Pustaka pelajar, 1999)., h. 3 


\section{PEMBAHASAN DAN HASIL PENELITIAN}

\section{Hakekat Manajemen}

Manajemen berasal dari kata manage dan dalam Bahasa latin manus, yang berarti memimpin, menangani, mengatur, atau membimbing. ${ }^{4}$ Marbun mendefinisikan manajemen sebagi penyelenggaraan koordinasi manusia dan fungsi-fungsi, hal mana dilakukan oleh manajer yang memimpin dan mengendalikan organisasi serta kegiatanya kearah sasaran yang terpilih sebelumnya. ${ }^{5}$

Begitu pentingnya peran manajemen sehingga kita dapat melihat bahwa manajemen dikenal sudah cukup lama bahkan telah diterapkan pada zaman kenabian terdahulu. Contohnya manajemen pada zaman nabi yusuf. Beliau merupakan seorang manajer yang sangat handal, selain sebagai seorang nabi beliau memiliki dua sifat yang patut dicontohi oleh seorang manajer, hal ini dijelaskan dalam al-Qur'an surah yusuf: 55

Hampir tidak dapat dipungkiri bahwa perkembangan manajemen sangat erat kaitannaya dengan perkembangan administrasi negara-negara maju sebagai akibat revolusi industri. Kebutuhan industri yang mengharapkan laba menunutut perbaikan dan peningkatan kerja (kinerja) melalui berbagai studi dan penelitian.

Dalam konteks manajemen sumber daya manusia, secara fungsional manajemen meliputi perencanaan, pengorganisasian, pelaksanaan, dan evaluasi. Manajemen sebagai peranan adalah, antar pribadi memberi informasi dan pengambilan keputusan manajemen dapat pula berarti pengembangan keterampilan yaitu teknis, manusiawi dan konseptor. ${ }^{6}$

Secara spesifik, subagyo berpendapat bahwa manajemen Pendidikan dengan memanfaatkan komponen-komponen Pendidikan. Pengertian manajemen Pendidikan adalah aktivitas memadukan sumber daya Pendidikan agar terpusat dalam mencapai tujuan Pendidikan yang ditetapkan. ${ }^{7}$

Subagyo kemudian merincikan hakekat manajemen mencakup perencanaan, pengorganisasian pelaksanaan dan evaluasi. ${ }^{8}$ Lebih cakupan manajemen diatas dapat diketegahkan sebagai berikut:

1. Perencanaan

Perencanaan pada hakekatnya merupakan suatu proses yang mengarah pada berbagai usaha untuk mencapai suatu tujuan. ${ }^{9}$ Perencanaan merupakan tindak

\footnotetext{
${ }^{4}$ Rosady Ruslan, manajemen humas dan manajemen komunikasi konsepsi dan aplikasi). (Jakarta: PT Raja Grafindo Persada, 1998)., h.1.

5 B.N, Marbun, konsep manajemen Indonesia, (Jakarta: bagian publikasi Lembaga Pendidikan dan pembinaan manajemen, 1980)., h. 5

${ }^{6}$ Faustino C. Gomes, manajemen sumber daya manusia, Yogyakarta: andi offset, 1997), h. 33

7 Subagio Atmodiwirio, Manajemen Pendidikan Indonesia (Jakarta, Ardadizjya jaya 2000), h. 84

${ }^{8}$ Subagio Atmodiwirio, Manajemen Pendidikan Indonesia. h, 87
} 
awal dalam aktifitas manajerial pada setiap organisasi. Karena itu perencanaan akan menentukan kinerja (performance) satu organisasi dengan organisasi lain dalam pelaksanaan rencana untuk mencapai tujuan. Mondy dan premeaux (dalam syafarudin ) menjelaskan bahwa perencanaan merupakan proses menentukan apa yang seharusnya dicapai dan bagaimana mewujudkan dalam kenyataan. ${ }^{10}$

Menurut terry (dalam syafrudin) mengemukakan Planning is the selecting and realiting of and the making and using of assumption regarding the future in the belive necessary to achieve desired results. Pendapat ini menjelaskan bahwa pendapat tiga unsur pokok dalam kegiatan perencanaan yaitu: pengumpulan data, analysis fakta, dan penyusunan rencana yang kongkrit. ${ }^{11}$

2. Pengorganisasian

Menurut pendapat mondy dan premeaux (1995) organisasi adalah kerja sama antara dua orang atau lebih dalam satu keadaan yang terkoordinir untuk mencapai hasil yang diinginkan. ${ }^{12}$ Pengorganisasian dapat diartikan juga sebagai keselulurahan proses pengelompokkan orang-orang, alat-alat, tugastugas, tanggung jawab dan wewenang sedemikian rupa, sehingga tercipta suatu kesatuan dalam rangka pencapaian tujuan yang telah ditetapkan. ${ }^{13}$

Pengorganisasian berdasarkan definisi diatas adalah pengelompokkan seluruh alat organisasi digerakkan untuk pencapaian tujuan yang telah ditetapkan. Oteng sutisna mengemukakan bahwa pengorganisasian sebagai kegiatan Menyusun struktur dan membentuk hubungan-hubungan agar diperoleh kesesuaian dalam usaha mencapai tujuan Bersama. ${ }^{14}$

Pengorganisasian organizing merupakan proses penyusunan struktur organisasi sesuai dengan tujuan organisasi, sumber daya -sumber daya yang dimilikinya., dan lingkungan yang melingkupnya. Dua aspek utama proses penyusunan struktur organisasi adalah departemen talisasi merupakan peeglompokkan kegiatan-kegiatan kerja suatu organisasi agar kegiatankegiatan yang sejenis dan saling berhubungan dapat dikerjakan Bersama. Pembagian kerja adalah perincian tugas pekerjaan agar setiap individu dalam organisasi bertanggung jawab untuk melaksanakan sekumpulan kegiatan yang terbatas.

9 H.A.R tilaar, Beberapa Agenda Reformasi Pendidikan Nasional, (Jakarta: Tera Indonesia, 1998)., h. 111

${ }^{10}$ Syafaruddin, Manajemen Lembaga Pendidikan Islam, (Jakarta: ciputat press,2005) h. 1

${ }^{11}$ Syafaruddin, Manajemen Lembaga Pendidikan Islam. h. 62

${ }^{12}$ Herson Anwar. "Standar Pengelolaan Pendidikan Dalam Perspektif Pengelolaaan Madrasah Aliyah Swasta." Tadbir: Jurnal Manajemen Pendidikan Islam 5.1 (2017): 15-27. 2000), h. 100

${ }^{13}$ Subagio Atmodiwirio, Manajemen Pendidikan Indonesia (Jakarta, Ardadizjya jaya

${ }^{14}$ Oteng Sutisna, Administrasi Pendidikan, Dasar Teoritis Untuk Praktek Profesioanl., cet. 1; bandung : angkasa, 1989), h. 205 
Pengorganisasian merupakan fungsi manajemen yang kedua dan merupakan Langkah strategis untuk mewujudkan suatu rencana organisasi. Menurut terry pengorganisasian adalah hubungan perilaku yang efektif diantara semua orang, karena mereka akan daoat bekerja sama secara efesisen dan mencapai kepuasan pribadi dalam melakukan pekerjaan dalam konteks pengaruh lingkungan untuk mencapai tujuan dan sasaran.

Berdasarkan pendapat di atas dapat dikekmukakan bahwa pengorganisasian merupakan usaha penciptaan hubungan tugas yang jelas antara personalia. Sehingga dengan demikian setiap orang dapat bekerja sama didalam kondisi yang baik untuk mencapai tujuan-tujuan organisasi.

3. Pelaksanaan (actuating)

Actuating atau pergerakan dalam manajemen didefiniskan sebagai keseluruhan proses pemberian motif bekerja kepada para bawahan sedemikian rupa sehingga merka mau bekerja dengan ikhlas demi tercapainya tujuan organisasi dengan efesiensi dalam ekonomis.

4. Evaluasi

Secara harfiah kata evaluasi berasal dari Bahasa inggris evaluation, dalam Bahasa arab Al-Taqdir, dalam Bahasa Indonesia berarti penilaian. Adapun dari segi istilah sebagaimana dikemukakan oleh edwind wandt dan Gerald w. brown (1977) evaluation refer to the act or process to determining the value of something. Menurut definisi ini istila evaluasi itu menunjuk kepada atau mengandung pengertian suatu Tindakan atau suatu proses untuk menentukan nilai dari sesuatu.

Ajaran Islam juga menaruh perhatian yang besar terhadap evaluasi tersebut. Allah SWT dalam firmanya dalam kitab suci al-qur'an memberitahukan kepada kita bahwa pekerjaan evaluasi terhadap manusia didik merupakan suatu tugas penting dalam rangkaian proses Pendidikan yang telah dilaksanakan oleh pendidik sebgaimana firman Allah SWT dalam surah albaqarah ayat 31-32:

Adapun komponen komponen yang terkait atau berpengaruh terhadap tercapainya mutu Pendidikan sesungguhnya bukanlah variable tunggal yang karenanya mudah untuk dideskripsikan, melainkan terdiri dari banyak variabel berpengaruh seperti ; pertama, siswa dengan berbagai kemampuan, lingkunganya (social, ekonomi, budaya dan geografis), intelegensi kepribadian, bakat dan minat. Kedua, guru terkait dengan kemampuan, latar belakang Pendidikan, pengalaman kerja, beban mengajar, kondisi social ekonomi, komitmen terhadap tugas, disiplin, kreatifitas dan lain sebagainya. Ketiga, kurikulum meliputi : landasan program dan pengembangan, garisgaris besar program pengajaran, metode, sarana dan tehnik penilaian. Keempat, pengelolaan madrasah. Kelima, proses belajar mengajar. Keenam 
supervisi dan monitoring. Ketujuh, pengelolaan dana. Kedelapan hubungan madrasah dan lingkungan dan kesembilan, sarana Pendidikan. Meliputi: alat peraga/alat praktek, laboratorium perpustakaan ruang keterampilan ruang uks , ruang serba guna, ruang kantor/ tata usaha, ruang BP, Gedung dan perabot lainya.

Bosker yang dikutip oleh armai arief, menjelaskan bahwa dari sisi organisasi, madrasah dikatakan efektif jika dikelola menurut struktur organisasi yang baik. Sehingga dapat meningkatlan penampilanya. Demikian juga madrasah dikatakan efektif jika dapat melakukan penyesuaian diri dengan lingkunganya secara fleksibel sehingga dapat terus survive (bertahan hidup). Dari aspek ekonomi madrasah dikatakan efektif jika mampu menghasilkan lulusan (output) sesuai dengan keinginan dan biaya Pendidikan yang cenderung murah. $^{15}$

Uraian di atas mengandung pemahaman bahwa kunci pokok penerapan manajemen pada sebuah Lembaga Pendidikan adalah efektivitas . efektivitas dalam kajian di atas menitikberatkan tiga aspek efektifitas yaitu :

1) Efektifitas dari segi struktur organisasi

2) Efektifitas dari segi kemampuan menyesuaikan diri dengan lingkungan pendidikanya; dan

3) Efektifitas dari aspek ekonomi bahwa, madrasah diakatakan efektif apabila mampu meluluskan siswanya dengan biaya yang relative murah.

Sehubungan dengan penrapan manajemen dalam Pendidikan arief mengemukakan bahwa manajemen dalam organisasi Pendidikan dapat diartikan sebagai segala sesuatu yang bekenaan dengan penggelolaan proses Pendidikan untuk mencapai tujuan yang telah ditetapkan, baik tujuan jangka pendek, maupun jangka Panjang. ${ }^{16}$

\section{Hakekat Kepemimpinan Kepala Sekolah}

Kepemimpinan yang dalam istilah asingnya disebut sebagai leadership umunya diartikan sebagai kemampuan untuk mengerakkan orang lain agar berpartisipasi secara aktif dan suka rela dalam mencapai tujuan berasama. Namun banayak ahli yang meberikan Batasan penegertian tentang makna kepemimpinan berdasarkan persepsi masing-masing. Carter F. Good yang dikutip dalam wany soemanto dalam bukunya "pengantar operasioanl administrasi Pendidikan "memberikan pengertian kepemimpinan atau leadership yaitu leadership is the ability and readines to inspire guide direct or manage other' kepemimpinan yaitu

\footnotetext{
${ }^{15}$ Armai Arief, Reformulasi Pendidikan Islam, (cet, 1; Jakarta: CRSD Press, 2005), h. 68

${ }^{16}$ Herson Anwar. "Standar Pengelolaan Pendidikan Dalam Perspektif Pengelolaaan Madrasah Aliyah Swasta." Tadbir: Jurnal Manajemen Pendidikan Islam, 2017, h 5.1
} 
kemampuan dan kesiapan untuk memberikan inspirasi, bimbingan, mengarahkan dan mengatur orang lain). ${ }^{17}$

Kepemimpinan sebagaimana yang disebutkan diatas memberi penjelasan bahwa pada pengertian yang pertama carter $\mathrm{V}$ good. ia menitik beratkan pada sikap kemampuan untuk membimbing danmengarahkan orang lain. Sedangkan pada pengertian yang kedua oleh geogre terry, Ia menitik beratkan pada kemampuan untuk mempengaruhi orang lain. Namun ada hal penting yang harus dikemukakan bahwa dari ke dua pengertian diatas belum ada mencantumkan unsur "kerja sama" sebagai komponen penting dalam kepemimpinan. Oleh karena itu, dalam konsep kepemimpinan diperlukan adanya kecapakan dan ketrampilan khusus untuk mengerakkan orang lain sesuai denga yang dimaksud sehingga akan tercipta suasana kerja sama yang baik antara sesame dalam kelompok. Kecakapan atau keterampilan yang dimaksudkan disni sering diistilakan sebagai "human relation"yaitu keseluruhan rangkaian hubungan baik yang bersifat formal antara atasan degan bawahan, atasan dengan atasan, bawan dengan bawahan yang harus dibina dan dipelihara sedemikian rupa untuk menciptakan suatu "team work" yang baik disertai dengan seuasana kerja sama yang intim dan harmonis dalam rangka pencpaian tujuan Bersama dalam berkelompok atau organisasi. ${ }^{18}$

Asumsi diatas dikuatkan oleh imam munawir bahwa jalinan harmonis antara pemimpin dan yang dipimpin adalah sangat menentukan, sebab kepemimpinan adalah hubungan yang era tantara eorang dan sekelompok orang yang berkumpul karena adanya kepentingan Bersama. Hubungan tersebut ditandai dengan tingkah laku yang bertujuan memberikan bimbingan. Arahan serta petunjuk kepada orang yang dipimpinya . ${ }^{19}$ Jadi, yang terpenting dalam kepemimpinan adalah bagaimana seorang pemimpin mampu memberikan pengaruh terhadap tingkah laku orang yang dipimpinya. Dengan demikian yang diharapkan oleh seorang pemimpin dalam lingkungan sekolah/madrasah, ia diharapkan mampu mengkoordinir semua sumber daya yang ada untuk kepentingan pengembangan Lembaga Pendidikan yang di pimpinya.

Sebelumnya telah dipaparkan bahwa intisari dalam kepemimpinanya adalah kemampuan membimbing,mengarahkan dan mempengaruhi tingkah laku orang lain atau yang dipimpinya sehingga dalam ajaran Pendidikan islam seseorang baru dikatakan pemimpin yang baik jika ia telah mampu memberikan arahan, bimbingan dan petunjuk yang baik atau menunjukkan jalan positif kepada orang yang dipimpinya. Kepala madrasah sebagai pemimpin (leader) seharusnya

\footnotetext{
${ }^{17}$ Wany Soemanto, Pengantar Operasional Administrasi Pendidikan (Surabaya; Usaha Nasional: 1982) h. 20

${ }^{18}$ Wany Soemanto, Pengantar Operasional Administrasi Pendidikan., h. 21

${ }^{19}$ Imam Munawir, Azas-Azas Kepemimpinan Dalam Islam, (Surabaya; Usaha Nasional; tt), h. 13
} 
dalam praktek sehari-hari selalu berusaha memperhatikan dan mempraktekkan delapan fungsi kepemimpinan di dalam kehidupan madrasah. ${ }^{20}$

Delapan fungsi kepemimpinan kepala madrasah tersebut diatas meliputi (a) dalam kehidupan sehari-hari kepala madrasah akan dihadapkan kepada sikap para guru, staf dan para siswa yang mempunyai latar belakang kehidupan., kepentingan serta tingkat sosial budaya yang berbeda sehingga tidak mustahil terjadi konflik antar individu bahkan antar kelompok. Dalam mengahadapi hal semacam itu kepala madrasah harus bertindak arif, bijaksana adil, tidak ada fihak yang dikalahkan atau dianakemasakan.

Kepala madrasah diharapkan selalu dapat menghargai apapun yang dihasilkan oleh mereka yang menjadi tanggungjawabnya. Penghargaan maupun pengakuan ini dapat diwujudkan dalam berbagai bentuk, seperti kenaikan pangkat, fasilitas,kesempatan mengikuti Pendidikan dan sebagainya (praising).

Tugas dan tanggung jawab kepala madrasah sebagai administrator adalah menyelenggarakan seluruh kegiatan Pendidikan dalam lingkungan madrasah yang dipimpinya dan mampu mendayagunakan semua sumber yang tersedia secara optimal. ${ }^{21}$ Kepala madrasah tidak bertanggung jawab atas kelancaran jalannya madrasah secara teknis akademik saja, akan tetapi segala kegiatan, keadaan lingkungan madrasah dengan kondisi dan situasi serta hubungan dengan masyarakat sekitarnya merupakan tanggung jawabnya pula.

\section{Konsep Kualitas Mutu Madrasah}

Kata kualitas mutu memiliki banyak definisi yang berbeda dan bervariasi, dari konvensional sampai yang lebih strategik. Definisi konfensional dari kualitas mutu biasanya mengambarkan karakteristik lansung dari sebuah produk seperti: performansi (performance), keandalan (reliability), mudah dalam penggunaan (ease to use), estetika (esthetics) dan sebagainya. Dalam ISO (Quality vocabulary) kualitas (mutu) didefinisikan sebagai totalitas suatu produk yang menunjang kemampuanya untuk memuaskan kebutuhan yang didispesifikasikan atau ditetapkan, kualitas (mutu) seringkali diartikan sebagai kepuasan pelanggan. (costumer satisfaction) atau konfirmasi terhadap kebutuhan. ${ }^{22}$

Dengan demikian tiga kategori produksi dapat didefinisikan disini, yaitu : (1) barang (goods), misalnya : mobil, computer, perhiasan dll., (2) perangkat lunak (software), misalnya: program computer, laporan keuangan, instruksi dalam sitem dll, (3) jasa (services), misalanya : perbankan, pendidikan, transportasi, asuransi, pergundangan, pelatihan dan lain-lain.disamping pengertian diatas kualitas (mutu) juga dapat diartikan sebagai segala sesuatu yang menentukan

\footnotetext{
${ }^{20}$ Imam Munawir, Azas-Azas Kepemimpinan Dalam Isl., h. 108

${ }^{21}$ Daryanto, H.M, Administrasi Pendidikan, (Jakarta: Rineka Cipta, 2005), h. 80

${ }^{22}$ Vincet Gaspersz Total Quality Management, (Jakarta: Gramedia Putra Utama, 2005). h.
} 
kepuasan pelanggan dan upaya perubahan kearah perbaikan terus menerus sehingga dikenal istila : Q-MATCH (Quality = meets, agree, terns, and changes). Kualitas (mutu) terdiri dari sejumlah keungulan/keistimewan produk, baik keistimewan langsung maupun atraktif yang memenuhi keinginan konsumen (masyarakat) dan dngan demikian memberikan kepuasan atas penggunaan produk atau jasa tersebut,. Kualitas terdiri dari segala segala sesuatu yang bebas dari kekurangan atau kerusakan.

Dengan demikian mutu sekolah/madrasah sebagai salah satu pilar pegembangan sumber daya mausia sangat penting maknanya bagi pmbangunan nasioanal. Dapat dikatakan masa depan bangsa terletak pada keberadaan sekolah/madrasah yang berkualitas (bermutu). Kondisi itu akan muncul apabila terdapat sekolah/madrasah yang berkualitas. Untuk itu upaya meningkatkan mutu madrasah merupakan titik strategis dalam upaya menciptakan Pendidikan yang berkualitas.

\section{EFEKTIVITAS MANAJEMEN KEPEMIMPINAN MADRASAH DI MAN 1 KABUPATEN GORONTALO}

Kepala madrasah yang berhasil yaitu dapat mencapai tujuan madrasah/ madrasah dan mampu menjalin hubungan kerja sama yang baik dengan semua komponen yang terkait dengan penyelengaraan Pendidikan dimadrasah tersebut, serta mampu melaksanakan peranannya sebagai seorang yang diberi tanggung jawab untuk memimpin madrasah.

Kepemimpinan merupakan salah satu fungsi manajemen yang sangat penting untuk mencapai tujuan sekolah/madrasah. Kondisi ini perlu di imbangi oleh kompetensi kepala madrasah sebagai pengelola Pendidikan yang mampu membawa institusinya kea rah tujuan yang ingin dicapai, kompetensi kepala madrasah yang ditunut antaralain adalah bagaimana merencanakan, mengelola dan memanfaatkan sumber daya yang ada dimadrasah melalui pengambilan keputusan yang tepat. Dalam konteks ini kepala madrasah harus memiliki kompetensi yang dapat menunjang segala tugasnya di madrasah, terutama dalam mengambil keputusan yang berkaitan dengan proses Pendidikan agar Pendidikan dimadrasah dapat berjalan efektif dan efesien.

Menyadari berpa rumitnya manajemen kepemimpinan seorang kepala madrasah, maka seorang kepala madrasah harus memiliki kompetensi sebagaimana yang diungkapkan oleh Kepala MAN 1 Kabupaten Gorontalo yaitu : kompetensi kepala madrasah dalam mendefinsikan masalah atau tujuan yang ingin dicapai, penetapan pilihan alternatif berdasarkan informasi yang tepat., kecepatan dan ketepatan prosedur dan pendekatan yang digunakan dalam proses pengambilan keputusan berdasrkan kesesuaian kondisi internal dan eksternal serta tindak lanjut pelaksanaan keputusan dimadrasah. Mengigat permasalahn yang timbul pada suatu madrasah tidak hanya diakibatkan oleh kepala madrasah yang 
tidak memperhatikan situasi, tetaoi bisa juga akibat kepala madrasah yang tidak mampu mengantisipasi semua akibat pengambilan keputusan yang telah diambil. ${ }^{23}$

Mencermati uraian tersebut, kepala madrasah dalam manajemen kepemimpinanya di MAN 1 Kabupaten Gorontalo dituntut memiliki kompetensi yang memadai diantara yang mencakup: 1) technical skills, berhubungan dengan kemampuan yang sangat diperlukan dalam mengimplementasikan tugas yang berkenaan dengan tugas operasional madrasah., 2) Human Skills, berhubungan dengan kemapuan untuk menciptakan usaha Kerjasama di lingkungan madrasah yang dipimpinya. Ketrampilan ini sangat diperlukan kepala madrasah dalam mengorganisasikan segenap sumber daya manusia yang ada untuk keperluan pencapaian tujuan madrasah, 3) conseptual skills, berhubungan dengan kemampuan kepala madrasah dalam melihat organsasi madrasah sebagai satu keseluruhan mengrganisir segala aspek dalam system kehidupan madrasah. Dengan demikian kompetensi kepala MAN 1 Kabupaten Gorontalo merupakan gambaran tentang kualitas seorang kepala MAN 1 Kabupaten Gorontalo yang ideal dalam mencpai tujuan madrasah.

Berdasarkan hasil pengamatan dan wawancara yang penulis lakukan dilokasi penelitian terhadap kepemimpinan Kepala MAN 1 Kabupaten Gorontalo dapat dilihat dari penerapan keterampilan dalam kepemimpinanya yang dijelaskan pembahasnya sebagai berikut:

\section{Keterampilan Teknis Manajerial}

Berdasarkan kondisi riil yang ditemui dilapangan,diperoleh gamabran kepala madrasah dalam kepemimpinanya memiliki keterampilan teknis manajerial yang baik dalam hal: memperhatikan metode, proses, dan Teknik dalam melaksnakan pengambila keputusan, memanfaatkan serta mendayagunakan sarana peralatan yang diperlukan dalam mendukung kepemimpinannya dimadrasah, berfikir analsistisdan rasional sehubungan dengan pemecahan permasalahan yang dihadapai dilingkungan madrasah, mencari berbagai konsenus atau menyamakan persepsi dalam memecahkan masalah, mampu mengenali situasi dan problemproblem sosial yang timbul dalam penyelenggaraan Pendidikan di madrasah, dengan memperhatikan situasi yang terdapat dilingkungan madrasah, serta dapat mengantisipasi semua akibat yang timbul dalam manajemen kepemimpinan di lingkungan madrasah. Pendapat dari salah seorang guru terhadap manajemen kepemimpinan kepala madrasah terkait dengan keterampilan tehnik bahwa kepala madrasah mampu menganalisis berbagai kejadian atau kecenderungan dalam mengantisipasi segala permasalah yang timbul dilingkungan madrasah, mampu

\footnotetext{
${ }^{23}$ Hasil Olahan Data Penelitian, Efektivitas Manajemen Kepemimpinanya di MAN 1 Kabupaten Gorontalo
} 
mengarahkan dan mengantispasikan berbagai kebijakan yang diambil dalam penyelenggaraan Pendidikan dimadrasah., melakukan survei untuk mempelajari berbagai persoalan yang timbul dilingkungan madrasah. Berusaha meneliti dan menentukan bagaimana sumber-sumber daya Pendidikan madrasah dapat diadakan serta dapat memperbaiki penampilan madrasah melalui berbagai kebijakan dan melahirkan etos kerja dan produktifitas yang tinggi dimadrasah.

\section{Keterampilan Teknik Manajerial Hubungan Manusia}

Hasil penilaian Ini sesuai dengan kondisi riil yang ditemukan dilapangan,dimana diperoleh gambaran kepala madrasah dalam menjalankan kepemimpnanya memiliki keterampilan hubungan manusia yang baik dalam hal : memahami perlaku bawahanya dan dapat bekerja sama dengan baik, memahami isi hati, sikap dan motif bawahanya dalam mengemukkan pendapat mereka menjalin komunikasi secara jelas dan efektif menciptakan kerja sama yang efektif kooperatif praktis dan diplomatis, berperilaku yang dapat diterima oleh semua warga madrasah, senatiasa menjaga integritasnya baik dalam sikap, perilaku maupun perbuatanya dalam kesempatan apapun untuk menjadi pusat perhatian serta bertindak arif, bijaksana dan adil kepada semua warga dimadrasah.

Berdasarkan hasil wawancara denagn guru Pendidikan Agama Islam secara garis besar mengatakan bahwa keterampilan tejnik manajerial hubungan manusia dalam kepemimpian kepala MAN 1 Kabupaten Gorontalo telah dilaksanakan oleh kepala madrasah dengan baik, dengan dititikbertakan pada hubungan manusiawi sehingga guru lebih terbuka terhadap permasalahan yang dihadapi dalam penyelenggaraan Pendidikan madrasah. Yang pada giliranya dapat meningkatakan motivasi kinerja guru dalam melaksanakan tugas sehari-hari. Namun penilaian ini tampaknya harus mengakui pula bahwa masih ada perbuatan kepala MAN 1 Kabupaten Gorontalo dalam melaksanakan manajemen kepemimpinanya belum mengacu pada hubungan manusawi., seperti tidak bersikap adil terhadap bawahan, dan belum sepenuhnya bersikap jujur terhadap kesalahan yang diperbuat bawahan. Hal ini disebutkan terakhir ini menurut Kepala MAN 1 Kabupaten Gorontalo "memang butuh keberanian dari seorang pemimpin karena tidak semua bawahan dapat menerima Ketika diberitahukan kesalahanya secara transparan. ${ }^{24}$

3. Keterampilan Tehnik Manajerial Konseptual

Berdasarkan hasil wawancara dengan guru dan kepala madrasah secara garis besar mengunkapkan bahwa keterampilan tehnik manajerial konseptual dalam pengambilan keputusan telah dilaksanakan oleh kepala MAN 1 Kabupaten Gorontalo dengan baik, karena ia mengakui bahwa kepala madrasah senantiasa

${ }^{24}$ Hasil Olahan Data Penelitian, Efektivitas Manajemen Kepemimpinanya di MAN 1 Kabupaten Gorontalo 
berusaha mningkatkan kompetensi yang dimiliki dengan menikuti perkembangan inovasi inovasi -inovasi Pendidikan melalui berbagai program pelatihan, penataran, seminar dan alternatif pendidikan lainnya, sehingga hal ini akan menjadikan suatu masukkan bagi saya dalam memilih dan menetapkan keputusan yang terbaik dalam pengembangan Pendidikan dimadrasah serta lebih memotivasi warga madrasah dalam melaksanakan tugasnya. ${ }^{25}$

Berdasarkan uraian diatas dapat diakui bahwa dalam manajemen kepemimpinan yang benar-benar efektif memang itu sulit, diperlukan adanya kompetensi yang baik dari kepala madrasah terutama yang berkaitan dengan : 1) keterampilan tehknik manajerial, 2) keterampilan tehnik manajerial hubungan manusia dan 3) keterampilan tehnik manajerial konseptual. Mengingat dalam manajemen kepemimpinan kepala madrasah menyangkut kegiatan-kegiatan Pendidikan dimadrasah pelaksanaannya memerluknan pilihan, yaitu memilihi mana yang terbaik dalam pelaksanaanya. Dalam hal ini seorang kepala madrasah memahami secara komperehensif permasalahan yang timbul dimadrasah, dan memahami timbulnya masalah yang besar apabila masalah tidak segera diselesaikan. Dari hasil temuan penelitian diperoleh bahwa implikasi manajemen kepemimipnan kepala madrasah dalam meningkatkan mutu Pendidikan di MAN 1 Kabupaten Gorontalo dapat dilihat dari bebrapa hal yang sekaligus menjadi upaya dalam meningkatkan mutu Pendidikan dilembaga Pendidikan tersebut sebagai berikut:

4. Kekuasaan dan kewenangan

Untuk mewujudkan efektivitas manajemen kepemimipnan kepala madrasah, maka dalam melaksanakan setiap program yang ada di madrasah, kepala MAN 1 Kabupaten Gorontalo tampaknya telah melakukan pembagian tugas kepada semua personil madrasah sesuai dengan latar belakang dan kemampuanya masing-masing sehingga setiap program dapat dilaksanakan secara efektif dan efesien.

Selanjutnya pendapat kepala MAN 1 Kabupaten Gorontalo itu sendiri tentang pembagian tugas yang ada di MAN 1 Kabupaten Gorontalo diperoleh keterangan bahwa kepala madrasah selalu memberikan tugas kepada seluruh personil madrasah disesuaikan dengan latar belakng dan kemampuannya masingmasing tanpa membeda-bedakan antara satu dengan yang lainya ${ }^{26}$ Hal lain yang sangat diharapkan oleh guru di lembaga pendidikan tersebut bahwa dalam melaksanakan kepemimpinannya Kepala MAN 1 Kabupaten Gorontalo memiliki karakter yang tidak dimiliki oleh orang lain dalam menentukan suatu kebijakan

${ }^{25}$ Hasil Olahan Data Penelitian, Efektivitas Manajemen Kepemimpinanya di MAN 1 Kabupaten Gorontalo

${ }^{26}$ Hasil Olahan Data Penelitian, Efektivitas Manajemen Kepemimpinanya di MAN 1 Kabupaten Gorontalo 
misalnya selalu dimusyawarahkan dengan personil Madrasah. ${ }^{27}$ Demikian pula pernyataan dari kepala tata usaha bahwa Kepala MAN 1 Kabupaten Gorontalo selalu memberikan tanggung jawab kepada semua personil Madrasah dengan pembagian tugas yang sama tidak membeda-bedakan orang lain. ${ }^{28}$

\section{Penetapan Program}

Selanjutnya temuan penelitian terhadap pandangan guru MAN 1 Kabupaten Gorontalo tentang cara kepala madrasah dalam menetapkan program dan RAPBS kepala madrasah bersama staf guru maupun tata usaha merancang program Madrasah dan RAPBS lalu dikonsultasikan dengan komite Madrasah setelah itu diadakan rapat antara Madrasah dengan komite Madrasah dalam hal ini orang tua siswa untuk menetapkan program Madrasah dan biaya madrasah yang dibutuhkan berdasarkan rancangan RAPBS tersebut. Untuk mencapai tujuan yang telah ditetapkan Kepala MAN 1 Kabupaten Gorontalo sangat perlu untuk mendorong seluruh guru dan staf tata usaha yang ada di Madrasah tersebut untuk benar-benar bekerja dan melaksanakan tugas dengan giat untuk mencapai apa yang diharapkan Untuk meningkatkan pengetahuan dan keterampilan guru guru dan staf tata usaha Kepala MAN 1 Kabupaten Gorontalo selalu mengadakan upaya inovasi tentang kegiatan belajar mengajar inovasi tentang sarana dan prasarana inovasi tentang kegiatan ekstrakurikuler dan lain sebagainya

6. Supervisi Program

Untuk meningkatkan pengetahuan dan Berdasarkan pengamatan bahwa kepala Limboto Gorontalo melakukan supervisi kegiatan belajar mengajar guru guru di kelas untuk mengetahui pelaksanaan program pembelajaran yang dilaksanakan oleh guru bidang studi di kelas masing-masing.

\section{KESIMPULAN}

Mutu pendidikan di MAN 1 Kabupaten Gorontalo secara umum adalah cukup baik yang terefleksikan dalam pelaksanaan tugas kepala sekolah dan guru sebagai tenaga profesional untuk bertanggung jawab pada tugas kewajibannya dan melaksanakan proses pendidikan dan pembelajaran yang ada dengan memperhatikan aspek-aspek baik yang berkaitan dengan kegiatan proses pendidikan dan pembelajaran maupun yang berkaitan dengan kegiatan administrasi yang harus dilengkapi oleh kepala madrasah maupun guru dalam memajukan pendidikan yang intensitasnya dilandasi etos kerja dan disiplin yang tinggi manajemen kepemimpinan kepala MAN 1 Kabupaten Gorontalo berjalan secara efektif yang menunjukkan oleh adanya kompetensi yang baik dari kepala

${ }^{27}$ Hasil Olahan Data Penelitian Efektivitas Manajemen Kepemimpinanya di MAN 1 Kabupaten Gorontalo

${ }^{28}$ Hasil Olahan Data Penelitian, Efektivitas Manajemen Kepemimpinanya di MAN 1 Kabupaten Gorontalo 
madrasah terutama yang berkaitan dengan :1) keterampilan teknik manajerial, 2) keterampilan teknik manajerial hubungan manusia, 3) keterampilan teknik manajer konseptual. Mengingat dalam manajemen kepemimpinan kepemimpinan kepala madrasah menyangkut kegiatan kegiatan pendidikan di Madrasah pelaksanaannya memerlukan pilihan maka kepemimpinan kepala MAN 1 Kabupaten Gorontalo telah melakukan pilihan yang terbaik dalam pelaksananya. Dalam hal ini kepala madrasah tampaknya memahami secara komprehensif permasalahan yang timbul di Madrasah dan memahami timbulnya masalah yang besar apabila masalah Tidak segera diselesaikan.

\section{DAFTAR PUSTAKA}

Anwar, H. Implementation of Education Management Standard in the Guidance of Private Islamic High School. Jurnal Pendidikan Islam UIN Sunan Gunung Djati, 2018

Standar Pengelolaan Pendidikan Dalam Perspektif Pengelolaaan Madrasah Aliyah Swasta. Tadbir: Jurnal Manajemen Pendidikan Islam, 2017

Arifin, Kepemimpinan Kepala Madrasah Dalam Meningkatkan budaya mutu Studi kasus di MIM Wumialo Gorontalo disertasi PPS UM Malang 2009

B N Marbun Konsep Manajemen Indonesia, Jakarta Bagian Publikasi Lembaga Pendidikan Dan Pembinaan Manajemen, 1980

Budiman Budiman Harman, Peran Supervisor dan Kaidah Pendidikan, Jakarta: Cahaya Makmur, 1999

Daryanto HM Administrasi Pendidikan, Jakarta Rineka Cipta 2005

Hadiyanto, Mencari Sosok Desentralisasi Manajemen Pendidikan di Indonesia, cet. 1; Jakarta; Rineka Cipta, 2004

Departemen Agama Republik Indonesia Petunjuk Peningkatan Mutu Pendidikan di Madrasah Jakarta Direktorat Jenderal pendidikan 2003

E Mulyasa, Menjadi Kepala Madrasah Profesional, Bandung rosdakarya, 2003

Abudi Nata Manajemen Pendidikan Mengatasi Kelemahan Pendidikan Islam Di Indonesia, Jakarta Bumi Aksara, 2003

H.Moefetie Wiriadihardja, Dimensi Kepemimpinan Dalam Manajemen, Jakarta Balai Pustaka 1987

Imam Munawir, Azas-Azas Kepemimpinan Dalam Islam, Surabaya Usaha Nasional, 2006

Ahmad Hasan, Strategi Madrasah Unggul Christmas, Risma shopee Yogyakarta, 2009

Made Pidarta, Perencanaan Pendidikan Dengan Pendekatan Sistem, Jakarta rineka Cipta, 1990

Rohiyat, Manajemen Madrasah Teori Dasar Dan Praktek, Bandung Refika Aditama, 2008 
Sugeng Listyo Prabowo, Manajemen Pengembangan Mutu Madrasah, UIN Malang press, 2008

Syaiful Sagala, Manajemen Berbasis Madrasah Masyarakat Strategi Memenangkan Persaingan Mutu, Jakarta Nimas multimas, 2004

Wahjosumidjo, Kepemimpinan Kepala Madrasah Tinjauan Teoritik Dan Permasalahannya, Jakarta PT Raja Grafindo Persada, 2007 